\title{
Expression of the antibody 14D9 in Nicotiana tabacum hairy roots
}

\section{Carolina Martínez}

\author{
Cátedra de Microbiología Industrial y Biotecnología \\ Facultad de Farmacia y Bioquímica \\ Universidad de Buenos Aires \\ Buenos Aires, Argentina \\ Junín 9566 piso 1113 \\ Tel: 541149648269 \\ Fax: 541149648200 ext.8377 \\ E-mail: carom@ffyb.uba.ar

\section{Silvana Petruccelli} \\ CIDCA \\ Facultad de Ciencias Exactas \\ Universidad Nacional de la Plata \\ Argentina \\ Calle 47 y 1161900 \\ La Plata, Argentina \\ Tel: 542214249287 \\ Fax : 542214254853 \\ E-mail: silvana@biol.unlp.edu.ar
}

\section{Ana María Giulietti}

Cátedra de Microbiología Industrial y Biotecnología Facultad de Farmacia y Bioquímica

Universidad de Buenos Aires

Buenos Aires, Argentina Junín 9566 piso 1113

Tel: 541149648269

Fax: 541149648200 ext.8377

E-mail: agiule@ffyb.uba.ar

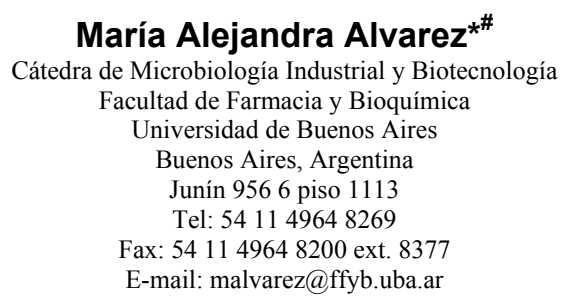

Financial support: This research was supported by CONICET and the University of Buenos Aires.

Keywords: catalytic antibodies, in vitro cultures, molecular farming, recombinant antibodies, tobacco.

Present address: "Fundación Pablo Cassará, Saladillo 2452, Ciudad de Buenos Aires, (C1144OFFX), Tel: 541148865242 , Fax: 54114065.

Abbreviations:

DMSO: dimethylsulfoxide;

ER: endoplasmic reticulum;

FW: fresh weight;

GI: growth index $=($ Final FW- Inicial FW $) /$ Initial FW;

PVP: polyvinylpyrrolidone;

TSP: total soluble protein.

Nicotiana tabacum hairy roots that express the antibody 14D9 were established. The 14D9 antibody yield obtained after 20 days of culture was $5.95 \mu \mathrm{g} 14 \mathrm{D} 9 \mathrm{ml}^{-1}$. The addition of the reticulum endoplasmic retention sequence KDEL demonstrated a positive effect over the intracellular 14D9 amounts with a yield increase up to $20.82 \mu \mathrm{g} \mathrm{ml}^{-1}$. DMSO increased the antibody amount in the biomass from 20.00 to $64.03 \mu \mathrm{g} \mathrm{ml}^{-1}$ while PVP (at 1.5 $\mathrm{gl}^{-1}$ ) and gelatine (at $5.0 \mathrm{gl}^{-1}$ ) increased total 14D9 amounts in the culture medium to $25 \mu \mathrm{g}$ and $14 \mu \mathrm{g}$ respectively.

*Corresponding author 
Transgenic plants are an economical alternative for largescale production of recombinant proteins for industrial and pharmaceutical uses. Most of the work has been performed in whole plant production methods; however, not many proteins can be produced in plants at high levels. Anyway a $0.1-1.0 \%$ TSP yield, the typical level obtained for the production of pharmaceutical proteins, is competitive enough in order to make plants economically viable. Besides, protein production in plant cells is safer than traditional techniques because of the lack of contamination with strange viral or bacterial materials, mammalian pathogens and other animal cell-culture contaminants. In vitro plant cell cultures appeared as an interesting alternative when a foreign protein has to be synthesized under controlled environmental conditions or when the product is required in a quicker way than that obtained by agriculture procedure (Hellwig et al. 2004). In addition, another important advantage of in vitro culture is the possibility to recover the foreign protein from the culture medium which reduces the cost of down stream processing. Taking into account all the aspects cited before, protein production costs could be reduced by as much as 1000 -fold compared with traditional production practices (Peterson and Arntzen, 2004). On the other hand, as the economic feasibility of plant-based systems depends on the concentration or titer of foreign protein accumulated, preventing the degradation or loss of product after its assembly and/or secretion therefore it is of vital importance. The fusion of a protein to the $\mathrm{C}$-terminal KDEL sequence for retention in and/or retrieve to the ER has been found to increase protein stability and to avoid addition of complex glycans in plant cells (Ko et al. 2003; Gomord et al. 2004). Also, the use of protein-stabilizing agents such as PVP and gelatine is one of the most promising methods for retaining foreign proteins secreted into plant culture medium. If the protein remains attached to biomass, permeabilising agents (such as DMSO) could be used (Magnuson, 1996; Wongsamuth and Doran, 1997).

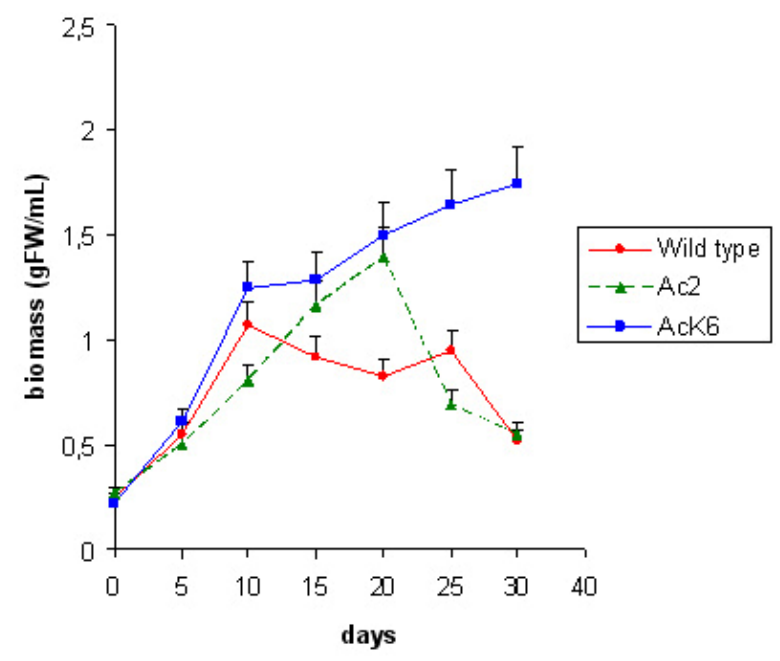

Figure 1. Time course of growth of $\boldsymbol{N}$. tabacum hairy root lines. Each point represents the mean of three replicates \pm SD. Time of culture: 30 days.
At present, in vitro cultures and particularly hairy roots have been recognized to be an alternative for foreign protein production. Hairy roots are a stable reproducible system which grows faster than suspension cell cultures and also they are able to grow in plant growth regulator-free culture medium. Considering all the proteins that have been produced in plants, perhaps the most promising ones are monoclonal antibodies and antibody fragments. However, there have been few reports on antibody production by hairy root cultures (Wongsamuth and Doran, 1997; Sharp and Doran, 2001). The aim of this work is to study the expression of the 14D9 antibody in Nicotiana tabacum hairy root cultures. 14D9 is a murine antibody IgG1 type which catalyzes the stereoselective transformation of achiral enol ethers having a practical appeal for organic synthesis. The kinetic constant for the reaction (kcat $=0.4 \mathrm{~s}^{-}$ $\left.{ }^{1}\right)$ makes this antibody one of the faster and most useful ones (Reymond et al. 1993; Zheng et al. 2003). Moreover, the effect of the KDEL retention signal and PVP, DMSO and gelatine on antibody production was also studied.

\section{MATERIALS AND METHODS}

\section{Plant material and culture conditions}

Seeds of wild type and two transgenic lines of $N$. tabacum expressing 14D9 murine monoclonal antibody were used. The difference between the two transgenic lines, Ac and $\mathrm{AcK}$, was the presence of the ER retention sequence KDEL in the last one.

\section{Initiation and maintenance of hairy root cultures}

Hairy roots of $N$. tabacum wild type and from the two transgenic lines $\left(\mathrm{Ac}_{2}\right.$ and $\left.\mathrm{AcK}_{6}\right)$ were induced by direct infection of leaves from 3 to 4 week old seedlings with a 48 hrs culture of Agrobacterium rhizogenes LBA 9402 according Alvarez et al. (1994). The 4-5 cm hairy root tips that appeared at the inoculation sites were excised and transferred to $150-\mathrm{ml}$ Erlenmeyer flasks containing $40 \mathrm{ml}$ MSRT liquid medium (Alvarez et al. 1993). Cultures were maintained according to Alvarez et al (1994) and transformation confirmed according to Hamill et al. (1987). Cultures were carried on an orbital shaker operated at 100 rpm, $24 \pm 2^{\circ} \mathrm{C}$ under a $16 \mathrm{hrs}$ photoperiod provided by white fluorescent lamps, with an irradiance of $1.8 \mathrm{w} \mathrm{m}^{-2}$ $\operatorname{seg}^{-1}$.

\section{Time-course of growth and antibody production}

With the purpose of studying the time-course of growth and antibody production, $200 \mathrm{mg} \mathrm{FW}$ of 15 days-old hairy roots of wild type and transgenic clones were inoculated into 250 Erlenmeyer flasks containing $40 \mathrm{ml}$ MSRT medium. Samples were taken every 5 days.

\section{Effect of additives}

DMSO was added to 14 days-old hairy root cultures of clones $\mathrm{Ac}_{2}$ and $\mathrm{AcK}_{6}$. The concentrations of DMSO used 

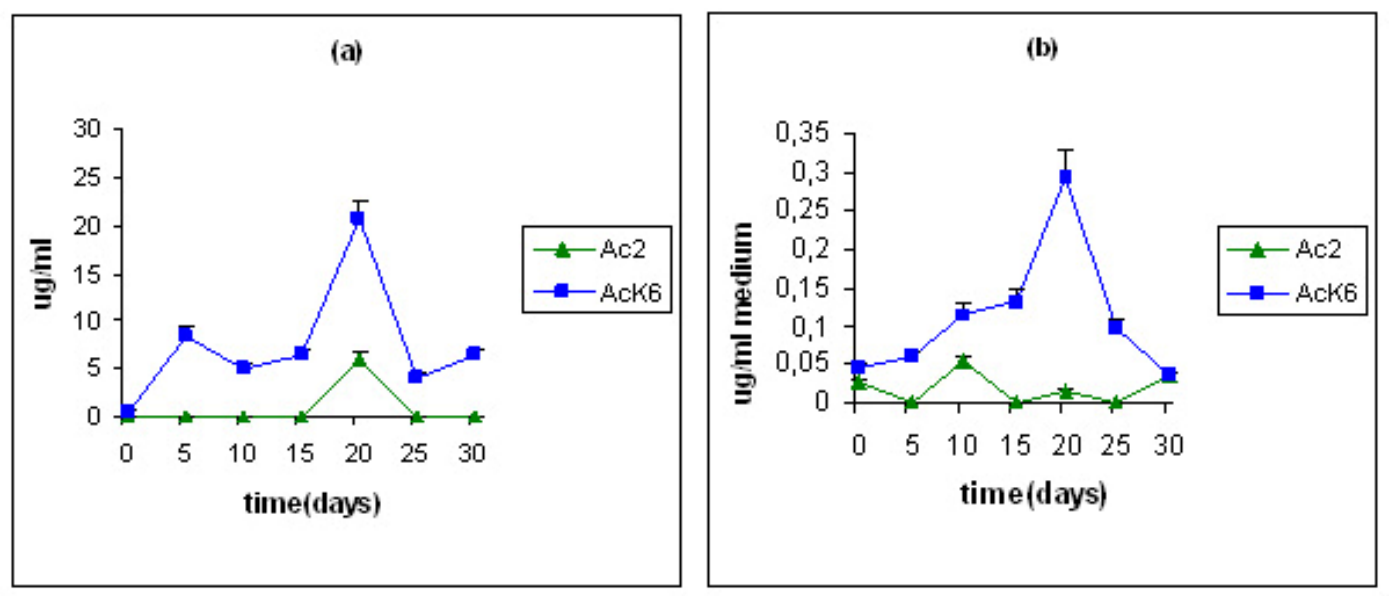

Figure 2. Time course of 14D9 expression by clones $A c K_{6}$ and $A c_{2}$ in:

\begin{abstract}
(a) biomass and,
(b) culture medium during 30 days of culture.

Each point represents the mean of three replicates \pm SD.
\end{abstract}

were $2.8 \%$ and $5 \% \mathrm{w} / \mathrm{v}$. Samples were taken at the beginning and on the $6,13,14,17,26$ and 33 day of culture. Gelatine (1.0, 5.0 or $\left.9,0 \mathrm{~g} \mathrm{l}^{-1}\right)$ and PVP $(1.0,1.5$ or $2.0 \mathrm{~g} \mathrm{l}^{-1}$ ) were added to 2 days-old AcK $_{6}$ hairy root clone cultures. Samples were taken on the 22 day of culture. Measurements of biomass, total protein content and antibody levels in the roots and culture media were carried out in all the experiments.

\section{Analytical methods}

Samples were harvested and dried under vacuum. Biomass was estimated as FW. For antibody extraction from the plant tissues the samples were grinded using a cold mortar and pestle in cold PBS $\left(0.24 \mathrm{~g} \mathrm{KH} 2 \mathrm{PO} 4 \mathrm{l}^{-1}, 1.44 \mathrm{~g}\right.$ Na2HPO4 $1^{-1}, 0.2 \mathrm{~g} \mathrm{KCl} \mathrm{l}^{-1}, 8 \mathrm{~g} \mathrm{NaCl} \mathrm{l}^{-1}$, pH: 7.0-7.2) containing $10 \mu \mathrm{g}$ leupeptin $\mathrm{ml}^{-1}$, then centrifuged at $14,000 \mathrm{~g}$ for $20 \mathrm{~min}$ in a cold chamber. Concentrations of antibodies possessing both heavy $(\gamma)$ and light $(\kappa)$ chains were measured in the biomass extracts and in the culture medium by sandwich ELISA using goat anti-mouse antibodies specific for $\gamma$ and $\kappa$ chains. Only antibodies assembled into $\gamma-\kappa$ chain complexes were measured. The ability of the antibodies to recognize the hapten was evaluated by direct ELISA and their integrity by Western blot. Western blot analysis was carried out with goat antigamma mouse chain-conjugated peroxidase used at 1:1000. The immune complexes were detected after incubation with Supersignal West Pico Chemiluminiscent Substrate (Pierce Chem.). Proteins were evaluated according to Bradford (1976) and proteases as described by Vázquez and MacCormack (2002). Transformation with A. rhizogenes LBA 9402 was confirmed according to Alvarez et al. (1994). Three replicates were used in all determinations and variance analysis was conducted in each test.

\section{Chemicals}

All the culture medium components and chemicals were purchased from Sigma Chemical Co.. PVP molecular weight: 10,000 . Kappa-chain specific goat anti-mouse IgG and gamma-chain specific goat anti-mouse IgG -HRP were purchased from Southern Biotechnology (Birmingham, $\mathrm{AL})$.

\section{RESULTS AND DISCUSSION}

\section{Establishment and selection of hairy root clones}

The frequency of root initiation was above $85 \%$. Several clones which present differences regarding growth as well as in antibody expression levels were obtained. Among the clones obtained we selected clones $\mathrm{Ac}_{2}$ and $\mathrm{AcK}_{6}$ for their characteristics of growth (high rate) and their capacity to express 14D9 antibody in an stable way. Hairy roots from line $\mathrm{AcK}_{6}$ grew faster and stronger than the wild type and line $\mathrm{Ac}_{2}$. That phenomenon is also observed in the whole plants and suspension cell cultures derived from $\mathrm{AcK}_{6}$ line. We could attribute it to the site of T-DNA integration in that transgenic line.

\section{Time-course of growth and antibody production}

Figure 1 shows clone $\mathrm{AcK}_{6}$ grew faster $\left(\mu=0.190\right.$ days $\left.^{-1}\right)$ than both the wild type $\left(\mu=0.105\right.$ days $\left.^{-1}\right)$ and clone $\mathrm{Ac}_{2}(\mu$ $=0.060$ days $\left.^{-1}\right)$. The 14D9 antibody yield obtained after 20 days of culture was $4.26 \mu \mathrm{g} \mathrm{g}^{-1} \mathrm{FW}\left(5.95 \mu \mathrm{gml}^{-1}\right)$ for clone $\mathrm{Ac}_{2}$ and $13.70 \mu \mathrm{g} \mathrm{g}^{-1} \mathrm{FW}\left(20.82 \mu \mathrm{gml}^{-1}\right)$ for clone $\mathrm{AcK}_{6}$. On the other hand, 14D9 antibody concentration expressed as \%TSP were 0.386 for clone $\mathrm{Ac}_{2}$ and9.34 for clone $\mathrm{AcK}_{6}$. The antibody yield (expressed as $\mu \mathrm{g} \mathrm{g}^{-1} \mathrm{FW}$ ) in line $\mathrm{AcK}_{6}$ was 3.21-fold higher than in line $\mathrm{Ac}_{2}$. Preventing the 


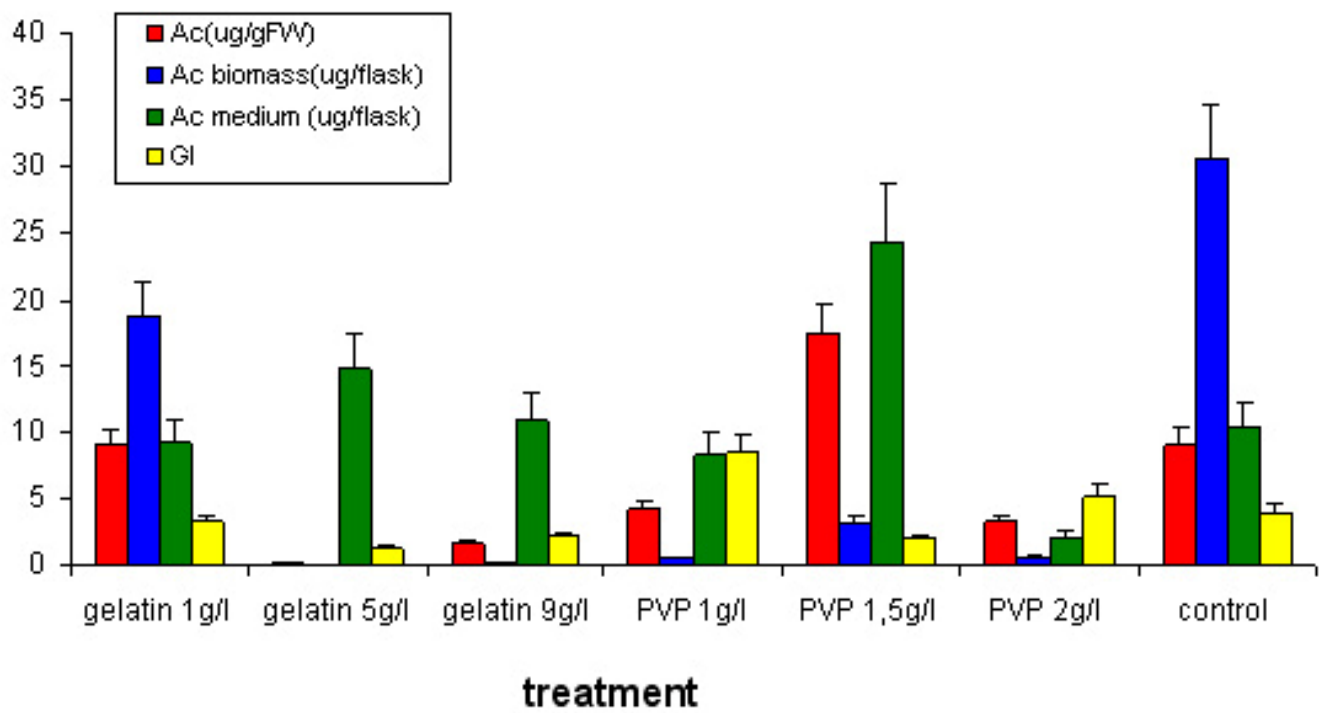

Figure 3. Growth index (GI), antibody yield in the biomass ( $\mu \mathrm{g} \mathrm{FW-1),total} \mathrm{amount} \mathrm{of} \mathrm{14D9} \mathrm{in} \mathrm{the} \mathrm{culture} \mathrm{medium} \mathrm{(} \mu \mathrm{g}$ 14D9 per flask) and in the biomass ( $\mu$ g 14Dp per flask) in 22 days-old $N$. tabacum AcK 6 hairy root clone with the addition of gelatine (1.0, 5.0 and $\left.9.0 \mathrm{~g} \mathrm{I}^{-1}\right)$, and PVP $\left(1.0,1.5\right.$ and $\left.2.0 \mathrm{~g} \mathrm{I}^{-1}\right)$. Gelatine and PVP were added to 2 days-old cultures. As control AcK 6 hairy root without any addition was used. Each point represents the mean of three replicates \pm SD.

secretion of protein by using the KDEL signal peptide for retention in the ER, has been found to minimize antibody fragmentation and improve antibody accumulation in plant cells (Tsoi and Doran, 2002). Also proteases in the secretory pathway and in the apoplast are avoided (Sharp and Doran, 2001). In the culture medium the highest values of antibodies were about $1 \%$ of the amounts reached in the biomass for both clones (Figure 2). Although at very low levels, $14 \mathrm{D} 9$ produced by $\mathrm{AcK}_{6}$ hairy root clones appeared into the culture medium probably due to cellular lysis, in contrast to the results obtained in transgenic plants. It was not detected the presence of proteases in the culture media of transgenic or wild type hairy roots. In addition, Western blots showed a band that corresponds to the complete antibody, no fragments were detected in any case. Functionality of the antibody was confirmed by direct ELISA.

\section{Culture treatments for increasing antibody accumulation and release}

In order to increase antibody level in the culture medium, gelatine, PVP and DMSO were added as it was described in Materials and Methods.

Gelatine. Figure 3 shows that gelatine at $5.0 \mathrm{~g} \mathrm{l}$-1 had a positive effect on antibody level in the culture medium. The maximum antibody concentration in the medium correspond to $14.0 \mu \mathrm{g}$ 14D9 per flask which is a. 1.44-fold the corresponding level in the control culture (Figure 3). On the other hand at gelatine concentrations higher than $1.0 \mathrm{~g} \mathrm{l}^{-}$ 1 antibody level in the biomass fell down. Probably the intracellular environment changed unfavourably making the antibody concentration in the biomass decrease significantly. These results are in agreement with those (a) $\quad \mathbf{u g} / \mathrm{ml}$
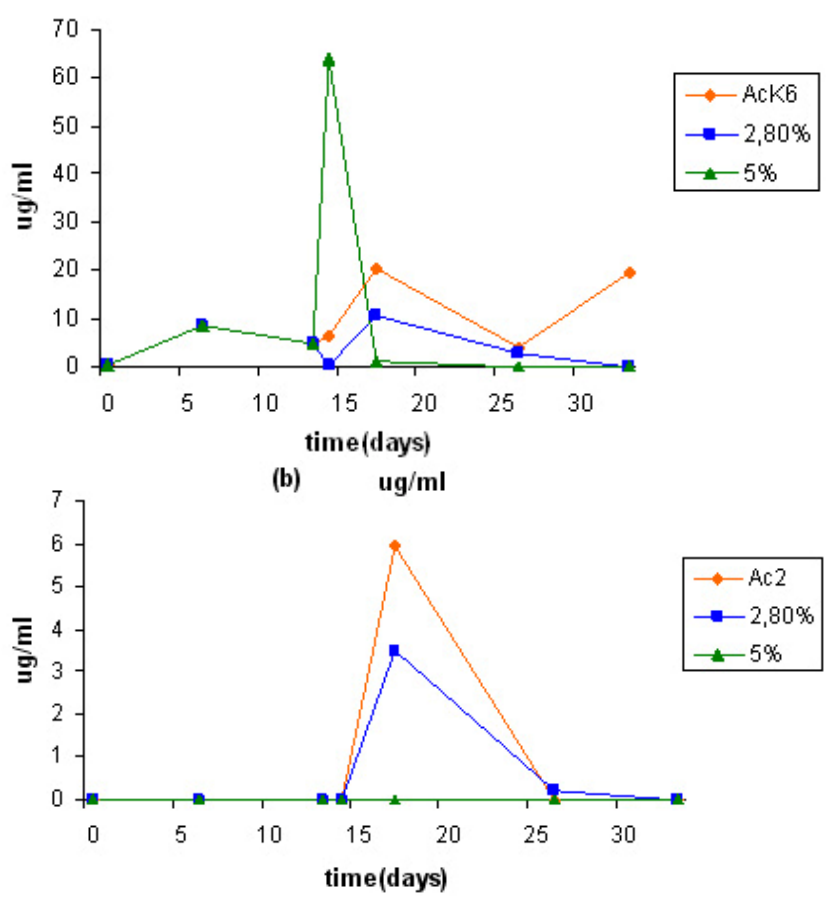

Figure 4. Time course of 14D9 expression in:

(a) AcK $_{6}$ hairy root clone cultures incubated with $2.8 \%$ or $5 \% \mathrm{v} / \mathrm{v}$ DMSO and,

(b) $\mathrm{Ac}_{2}$ hairy root clone cultures incubated with $2.8 \%$ or $5 \% \mathrm{v} / \mathrm{v}$ DMSO.

DMSO was added into 14 days-old cultures. As a control AcK $_{6}$ hairy root culture without the addition of DMSO was used. Each point represents the mean of three replicates \pm SD. 


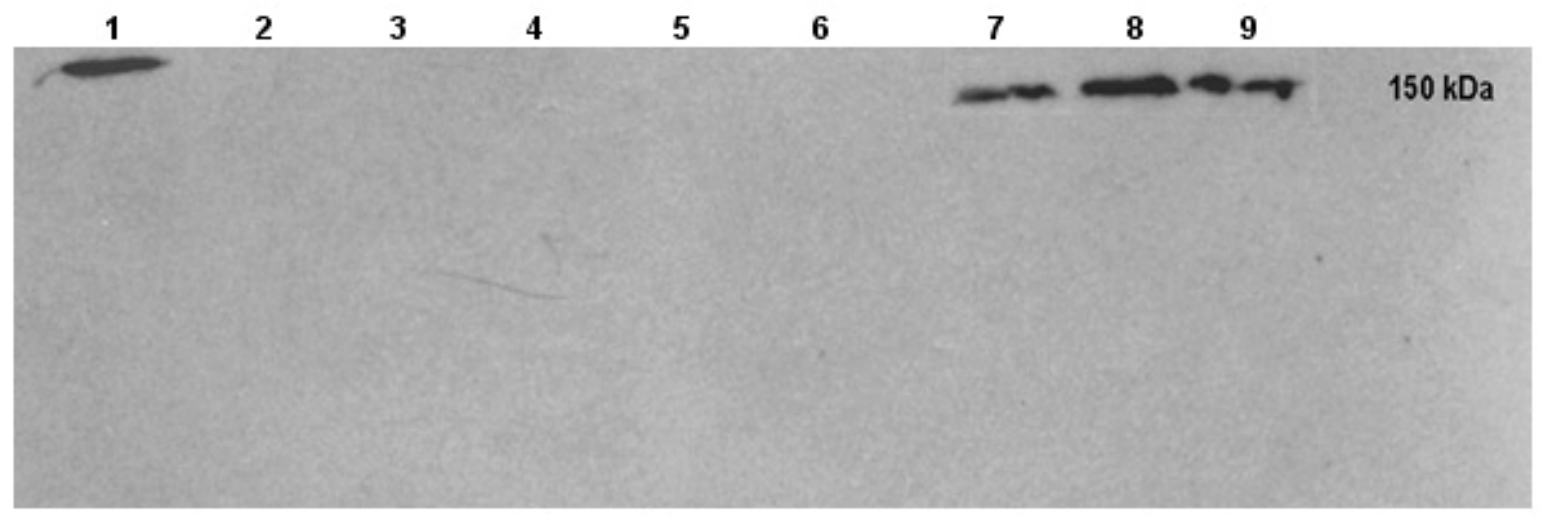

Figure 5. Western-blot of hairy root biomass. The lines were loaded with equal volumes of samples. Line 1: Standard IgG Antibody; line 2: N. tabacum wild type; line 3: N. tabacum wild type +5\% DMSO; line 4: $\mathrm{Ac}_{2}+2.8 \% \mathrm{DMSO}$; line 5: $\mathrm{Ac}_{2}+5 \% \mathrm{DMSO}$ line 6: $\mathrm{Ac}_{2}$ control; line 7: $\mathrm{AcK}_{6}+2.8 \% \mathrm{DMSO}$; line 8: $\mathrm{AcK}_{6}+5 \%$; line 9: $\mathrm{AcK}_{6}$ control. Coating: gaot anti gamma mouse chain conjugated with peroxidase $(1: 1000)$ in $1 \%(P / V)$ non fat milk. Antibody binding was detected after incubation with Supersignal West Pico Chemiluminiscent Substrate (Pierce Chem.) after 25 min of exposure.

reported by Lee et al. (2002) working with $N$. tabacum cell suspension cultures expressing the human granulocytemacrophage colony stimulating factor (hGMCSF).

PVP. PVP is a versatile polymer which is water soluble, exhibiting excellent complexing, stabilizing and colloidal properties while at the same time being metabolically and physiologically inert (Magnuson et al. 1996). In our work, with the addition of $1.5 \mathrm{~g}$ PVP $1^{-1}$, the antibody concentration in culture media was significantly enhanced by 2.38 -fold (Figure 3 ). The increased recovery cannot be attributed to antibody artifactual increases because of cell death or breakage. Therefore, the results suggest that PVP possibly functions preventing denaturation and adherence to surfaces in the culture vessel of the secreted protein. Similar results have been reported previously for tobacco cell suspension cultures (Magnuson et al. 1996; Wongsamuth and Doran, 1997).

DMSo. 14D9 antibody level in clone $\mathrm{AcK}_{6}$ increased in about three times at the 20 day of culture using DMSO at a concentration of $5 \% \mathrm{v} / \mathrm{v}$ (Figure $4 \mathrm{a}$ ). The increase of the antibody level into the biomass could be attributed to DMSO producing small channels which do not allow the antibody release. These channels would favour the entrance of small molecules of nutrients which may increase the synthesis of the antibody in the biomass. The increased metabolic activity should increase not only the 14D9 level but also other proteins. In our experiment total soluble protein content in the biomass also increased from $13.6 \mu \mathrm{g}$ $\mathrm{ml}^{-1}$ to $20.87 \mu \mathrm{g} \mathrm{ml}^{-1}$. DMSO could also stabilize proteins against denaturation by forming hydrogen bonds with proton-donor groups on protein molecules (Hendersen et al. 1975). However, DMSO was not effective for increasing the release of the antibody in the culture medium, the levels remained approximately the same than those of the control (Figure 4b). The size of $14 \mathrm{D} 9$, about $150 \mathrm{kDa}$, may be too big to pass through the pores created by the permeabilizing action of DMSO. It has been shown that molecules with a molecular weight greater than 5,000 have difficulty passing through the cell wall even after permeabilization with DMSO concentrations up to $7.5 \%$ (Carpita et al. 1979; Wahl et al. 1995). Western blots did not show any antibody fragment Neither in the biomass nor in the culture medium (Figure 5).

\section{CONCLUDING REMARKS}

We demonstrated the ability of N. tabacum hairy roots to express the antibody 14D9 in a stable way in time. As far as we know, this is the first report about the use of the KDEL sequence to improve antibody expression in hairy root cultures. In our work the KDEL sequence showed a beneficial effect on antibody yields. From our results we could establish that both the addition of PVP $\left(1.5 \mathrm{~g}^{-1}\right)$ and gelatine $\left(5.0 \mathrm{~g} \mathrm{l}^{-1}\right)$ enhanced antibody accumulation in hairy root culture media probably by protecting the antibody to some extent. No antibody fragment was detected into the medium. DMSO at $5.0 \%(\mathrm{~V} / \mathrm{V})$ concentration had a positive effect on antibody accumulation in the biomass of $\mathrm{AcK}_{6}$ hairy root cultures. As Wahl et al. (1995) reported before, we found that the effect of the increasing of the DMSO concentration on antibody production was more drastic for intracellular production than for extracellular. The hairy roots accumulated by $13-15 \%$ with respect to the antibody titers typically obtained in batch hybridoma cultures (Bibila and Filckinger, 1991; Miller et al. 1988). In contrast with hybridoma cells, however, most of the antibody remained associated with the root tissue rather than being secreted extracellularly. The controversial results informed by different authors lead us to the conclusion that the influence of additives such as permeabilizant and stabilizers must be studied and optimized according to the plant cell tissue culture for each expressed antibody in order to establish a competitive production system. 


\section{ACKNOWLEDGMENTS}

MAA and AMG acknowledges support from Argentina National Research Council (CONICET) and University of Buenos Aires (UBA). MAA, AMG and SP are members of the Researcher Career of the National Research Council (CONICET).

The authors wish to thank Ms Malena Lanza for her technical support and Dr Rita Stumpo for her wise advices.

\section{REFERENCES}

ALVAREZ, María A.; MIRANDA, María V.; CASCONE, Osvaldo and GIULIETTI, Ana M. Peroxidase production by Armoracia lapathifolia transformed roots. In: GUSTINE V.L. and FLORES H. eds. Phytochemical and Health. American Society of Plant Physiology. 1994, p. 305-307.

ALVAREZ, María A.; NIGRA, Hilda M. and GIULIETTI, Ana M. Solasodine production by Solanum eleagnifolium Cav. in vitro cultures: Influence of plant growth regulators, age and inoculum size. Large-scale production. Natural Product Letters, May 1993, vol. 3, no. 1, p. 9-19.

BIBILA, Theodora A. and FILCKINGER, Michael C. A model of interorganelle monoclonal antibody transport and secretion in mouse hybridoma cells. Biotechnology and Bioengineering, October 1991, vol. 38, no. 7, p. 767-780.

BRADFORD, Marion M. A rapid and sensitive method for the quantification of microgram quantities of protein utilizing the principle of protein-dye binding. Analytical Biochemistry, May 1976, vol. 72, p. 248-254.

CARPITA, N.; SABULARSE, D.; MONTEZINOS, D. and DELMER, D.P. Determination of the pore size of cell walls of living plant cells. Science, 1979, vol. 205, p. 1144-1147.

GOMORD, Véronique; SOURROUILLE, Christophe; FITCHETTE, Anne-Catherine; BARDOR, Muriel; PAGNY, Sophie; LEROUGE, Patrice and FAYE, Loïc. Production and glycosylation of plant-made pharmaceuticals: the antibodies as a challenge. Plant Biotechnology Journal, March 2004, vol. 2, no. 2, p. 83100.

HAMILL, J.D.; PARR, A.J.; RHODES, M.J.C.; ROBINS, R.J. and WALTON, N.J. New routes to plant secondary products. Biotechnology, 1987, vol. 5, p. 800-804.

HELLWIG, S.; DROSSARD. J.; TWYMAN, R.M. and FISCHER, R. Plant cell cultures for the production of recombinant proteins. Nature Biotechnology, November 2004, vol. 22, no. 11, p. 1415-1422.

HENDERSON, T.R.; HENDERSON, R.F. and YORK, J.L. Effects of dimethyl sulfoxide on subunit proteins. Annals of the New York Academy of Sciences, 1975, vol. 243, p. 3853.
KO, Kisung; TEKOAH, Yoram; RUD, Pauline M.; HARVEY, David J.; DWEK, Raymond A.; SPITSIN, Sergei; HANLON, Cathleen, A.; RUPPRECHT, Charles; DIETZSCHOLD, Bernhard; GOLOVKIN, Maxim and KOPROWSKI, Hilary. Function and glycosylation of plantderived antiviral monoclonal antibody. Proceedings of the National Academy of Sciences of the United States of America, 2003, vol. 100, no. 13, p. 8013-8018.

LEE, Jae-Hwa; KIM, Nan-Sun; KWON, Tae-Ho; JANG, Yong-Suk and YANG, Moon-Sik. Increased production of human granulocyte-macrophage colony stimulating factor (hGM-CSF) by the addition of stabilizing polymer in plant suspension cultures. Journal of Biotechnology, July 2002, vol. 96, no. 3, p. 205-211.

MAGNUSON, Nancy S.; LINZMAIER, P. Michael; GAO, Jian-Wei; REEVES, Raymond; GYNHEUNG, An and LEE, James M. Enhanced recovery of a secreted mammalian protein from suspension culture of genetically modified tobacco cells. Protein Expression and Purification, March 1996, vol. 7, no. 2, p. 220-228.

MILLER, W.M.; BLANCH, H.W. and WILKE, C.R. A kinetic analysis of hybridoma growth and metabolism in batch and continuous suspension culture: Effect of nutrient concentration, dilution rate, and $\mathrm{pH}$. Biotechnology and Bioengineering, October 1988, vol. 32, no. 8, p. 947-965.

PETERSON, Robert K.D. and ARNTZEN, Charles J. On risk and plant-based biopharmaceuticals. Trends in Biotechnology, February 2004, vol. 22, no. 2, p. 64-66.

REYMOND, Jean Louis; JAHANGIRI, Guiti K.; STOUDT, Catherine and LERNER, Richard A. Antibody catalyzed hydrolysis of enol ethers. Journal of the American Chemical Society, 1993, vol. 115, no. 10, p. 3909-3917.

SHARP, Janet M. and DORAN, Pauline M. Strategies for enhancing monoclonal antibody accumulation in plant cell and organ cultures. Biotechnology Progress, 2001, vol. 17, no. 6, p. 979-992.

TSOI, Bonny M-Y and DORAN, Pauline M. Effect of medium properties and additives on antibody stability and accumulation in suspended plant cell cultures. Biotechnology and Applied Biochemistry, 2002, vol. 35, no. 3, p. 171-180.

VÁZQUEZ, Susana C. and MAC CORMACK, Walter. Effect of isolation temperature on the characteristics of extracellular proteases produced by Antarctic bacteria. Polar Research, 2002, vol. 21, no.1, p. 63-71.

WHAL, M.F.; AN, G.H.A. and LEE, J.M. Effects of dimethyl sulfoxide on heavy chain monoclonal antibody production from plant cell culture. Biotechnology Letters, 1995, vol. 17, no. 5, p. 463-468. 
WONGSAMUTH, Raviwan and DORAN, Pauline. Production of monoclonal antibodies by tobacco hairy roots. Biotechnology and Bioengineering, June 1997, vol. 54 , no. 5, p. 401-415.

ZHENG, Lei; BAUMANN, Ulrich and REYMOND, Jean Louis. Production of a functional catalytic antibody $\mathrm{ScFv}$ NusA fusion protein in bacterial cytoplasm. Journal of Biochemistry, May 2003, vol. 133, no. 5, p. 577-581. 